\title{
Young Ireland and Irish Revolutions
}

La Jeune Irlande et les révolutions irlandaises

\section{Frank Rynne}

\section{OpenEdition}

\section{Journals}

Electronic version

URL: http://journals.openedition.org/rfcb/265

DOI: $10.4000 / \mathrm{rfcb} .265$

ISSN: 2429-4373

\section{Publisher}

CRECIB - Centre de recherche et d'études en civilisation britannique

\section{Printed version}

Date of publication: 1 September 2014

Number of pages: 105-124

ISSN: 0248-9015

\section{Electronic reference}

Frank Rynne, "Young Ireland and Irish Revolutions », Revue Française de Civilisation Britannique

[Online], XIX-2 | 2014, Online since 01 May 2015, connection on 02 May 2019. URL : http:// journals.openedition.org/rfcb/265; DOI : 10.4000/rfcb.265

\section{(c) $($ i) $(9)$}

Revue française de civilisation britannique est mis à disposition selon les termes de la licence Creative Commons Attribution - Pas d'Utilisation Commerciale - Pas de Modification 4.0 International. 


\title{
Young Ireland and Irish Revolutions
}

\author{
Frank RYNNE \\ Université Panthéon-Assas (Paris II)
}

In the early 1840 s the political atmosphere in Ireland was tense and was defined by the Repeal Movement led by Daniel O'Connell in the manner of his successful campaign which achieved Catholic Emancipation in 1829. The Repeal Movement sought to repeal the Act of Union which joined Ireland and Britain constitutionally in 1801. O'Connell, a former Freemason, achieved his early success by both the mass mobilisation of the majority Catholic population and the support of liberal Protestants. The Repeal Movement followed a similar approach, and from the early 1840s, gained the support of a group of young intellectuals, political strategists and poets, who became known as Young Ireland. ${ }^{1}$ Many leading Young Irelanders, such as Thomas Davis, John Mitchel and a later founder of the Fenian movement, Thomas Clarke Luby, were Protestant. Though Catholics had been given a limited franchise in 1793, emancipation allowed them to sit in Parliament. Though this entry into political life had seemed to offer hope of concessions in the early 1830 s, by 1843 O'Connell disillusioned with Westminster, was organising monster Repeal meetings which attracted hundreds of thousands of people.

The historian J. S. Donnelly Jr covered the subject of Irish politics during the 1840s in a chapter entitled 'A Famine in Irish Politics'. ${ }^{2}$ It is possible to characterise Irish political activity in the 1840 s as comprising humiliation, collaboration and subjugation. Humiliation when, in 1843, O'Connell cancelled a Repeal Meeting that was expected to be attended by one million people; collaboration in 1846 when O'Connell aided Lord John Russell's bid for government and received insignificant return for this support; and subjugation from 1848 when John Mitchel was transported to Tasmania and the armed rising led by the aristocratic William Smith O'Brien was stopped in its tracks by a handful of policemen barricaded in the house of a widow named McCormack in Ballingarry, Co. Tipperary. These latter events led to further Young Irelanders being transported and many others going into exile. Though failure may be the verdict delivered on Irish politicians of the decade, Donnelly notes the revolutionary political movement that arose from the events and writings of the 1840s. It is possible to credit the political thinkers and Young Ireland revolutionaries of the 1840s for the revival and articulation of Irish revolutionary organisation and ideology right down to the revolutionary period from 1913-23. ${ }^{3}$ In

${ }^{1}$ Patrick M. GEOGHEGAN, King Dan: The Rise of Daniel O'Connell, 1775-1829, Dublin: Gill and Macmillan, 2008, p. 49.

2 James S. DONNELLY, Jr, 'The Great Irish Potato Famine', pp. 356-71 in W.E. VAUGHAN, (ed.) A New History of Ireland V, Ireland Under The Union 1801-1870, Oxford: Oxford University Press, 1989.

${ }^{3}$ Ibid., pp. 369-71; Frank RYNNE, Permanent Revolutionaries: The IRB and the Land War in Skull, Co. Cork, 1879-82, PhD Thesis, Trinity College Dublin, January 2014, pp. 28-9. 
a pamphlet, The Sovereign People, written just before the 1916 Easter Rising, one of its leaders, Pádraig Pearse, glorified Theobald Wolfe Tone, Thomas Davis, John Mitchel, and James Fintan Lalor as the authors of the gospels of Irish republicanism. ${ }^{4}$ The latter three of these four evangelists were Young Irelanders. To examine Young Ireland's impact on Irish politics, it is necessary to look at the general history of the movement, its radicalisation, its changing ideology and the aftermath of 1848 Rebellion. Though the Great Famine was used in later republican propaganda, it was the developments in political thought in the 1840s and the reality of both political and revolutionary failure in the decade that caused a small section of society to band together to foment revolution. The poignant feature of this is not the exact causes of disaffectation, but rather the direct action which would provide a remedy. Despite its limited appeal in general, from 1848 onwards, physical force rather than constitutional methods, once the idea permeated and was promoted by activists, was never fully removed from Irish political discourse. The political lessons learned by members of the Repeal Movement and the Confederation, which split from it, as well as the public and private debates that took place in the late 1840 s, set the agenda for a separatist movement that eschewed constitutional methods in favour of armed revolution in order to separate Ireland from the United Kingdom.

To examine these developments it is necessary to chart the political developments in the 1840s and explore the radical change in tactics amongst a significant few who shunned constitutional methods and moral force and adopted revolutionary positions advocating physical force. It is clear that the 1840 s, rather than being a famine in politics, was a decade which fundamentally changed the aspirations of many newly emancipated Catholics and indeed liberal Protestants from seeking mere repeal to seeking total separation of Ireland from Britain by the use of armed force.

\section{The origins of Irish republicanism and of the Orange Order}

Two reciprocal acts, the Acts of Union 1800, passed by the parliaments of Great Britain and Ireland respectively, effected the constitutional joining of Ireland with Great Britain in $1801 .^{5}$ The United Kingdom of Great Britain and Ireland comprised England, Scotland, Wales and Ireland. Thus, Ireland was constitutionally brought into the heart of British political life. The measure was a cynical exercise designed to both dull and control Irish political ambitions in the aftermath of the French assisted 1798 Rebellion. The 1798 Rebellion was a direct result of the American and French Revolutions which had a profound influence on the radical thinkers influenced by the Enlightenment in Ireland. The United Irishmen, founded in 1791 by, amongst others, Protestants Wolfe Tone, William Drennan and Napper Tandy, brought the influence of the French Revolution and demands for

4 P. H. PEARSE, The Sovereign People, Dublin: Whelan \& Son, 1916. Available online at the National Library of Australia: <http://nla.gov.au/nla.aus-vn5548546-s5> [accessed 1 June 2014].

${ }^{5}$ Union with Ireland Act 1800, 39 \& 40 Geo. 3 c. 67 [G.B.] (2 July 1800), passed by the parliament of Great Britain and the Act of Union (Ireland) 1800, 40 Geo. 3 c. 38 [Ire.] (1 Aug. 1800), which was passed by the Irish parliament in Dublin. 
independence to the fore. Tone's 1791 pamphlet, An Argument on Behalf of the Catholics of Ireland, advocated full emancipation for and partnership with Catholics in order to achieve independence, ending with the '[...] cry, Reform and the Catholics; and Ireland is free, independent and happy'. ${ }^{6}$ However, there was much opposition to such notions in Ireland, including from other secret societies. The Peep O'Day Boys were a Protestant secret society that was firmly loyal to a Protestant monarchy and a Protestant Ascendancy. In reaction to Peep O'Day Boys, a Catholic agrarian secret society, the Defenders, was formed. ${ }^{7}$ On September 21st 1795, following the Battle of the Diamond between Defenders and Peep O'Day Boys near Loughall, Co. Antrim, the victorious Peep O'Day Boys made their way to Loughall and founded the Orange Order. ${ }^{8}$ It must be noted that Presbyterians, also known as dissenters, were among the founders and supporters of the radical United Irishmen. Indeed, one Catholic United Irishman, Daniel O'Connell, would later condemn the risings of 1798 and Robert Emmet's of $1803 .{ }^{9}$ The 1798 Rebellion is characterised by a rising in the north of the country under the leadership of Presbyterians and one in Co. Wexford under the leadership of Catholic priests. Both met with similar fates, complete military defeat, followed by the military and yeomanry exacting a brutal price and instituting a reign of sectarian terror. The sectarian nature of the rising in the south and the disillusion of Presbyterians in their own leaders, who had spurred them to revolution only to abandon them, left Tone's dream in ashes. ${ }^{10}$ Tone was captured, in August 1798; months after the rising had been crushed, after French navy ship Hoche surrendered at Lough Swilly, Co. Donegal. He was tried and sentenced to death but he cheated the executioner, attempting suicide by slitting his

\footnotetext{
${ }^{6}$ Theobald Wolfe TONE, An Argument on Behalf of the Catholics of Ireland, Belfast: Society of the United Irishmen, 1791, p. 31.

7 James KELLY, 'Politics and Administration in Ireland, 1770-1815', UCC Multitext Project in Irish History: <http://multitext.ucc.ie/d/Politics_and_Administration_in_Ireland_17701815> [accessed 10 June 2014].

${ }^{8}$ Jonathan BARDON, A History of Ulster, Belfast: The Blackstaff Press, 1992, pp. 225-6.

${ }^{9}$ GEOGHEGAN, King Dan, op. cit., pp. 47-8; Patrick M. GEOGHEGAN, Robert Emmet, A Life, Dublin: Gill \& Macmillan, 2008, pp. 155-82; for a personal account of the Emmet rebellion see Miles BYRNE, Notes of an Irish Exile of 1798 being the chapters from Miles Byrne's Book relating to Ireland, Dublin: Maunsel \& Company, 1907, pp. 241-286. Note: Christine Kinealy states that 'O'Connell opposed the United Irishmen' in Christine KINEALY, Repeal and Revolution: 1848 and Ireland, Manchester: Manchester University Press, 2009, p. 23, citing Oliver MACDONAGH, The Hereditary Bondsman: Daniel O'Connell 1775-1829, New York, St. Martin's Press, 1987, p. 50. O'Connell in the early 1840s stated: 'I myself was a United Irishman', see William J. O'NEILL DAUNT, Personal Recollections of the Late Daniel O'Connell, M.P. 2 Vols., London: Chapman and Hall, 1848, vol. 2, p. 99. In his earlier life, O'Connell never claimed to have been in the United Irishmen, but in the 1840s he did make the admission in private at a time when the United Irishmen were being rehabilitated in Irish historical discourse. He also confirmed his membership to a group of visitors in 1844, see GEOGHEGAN, King Dan, op. cit., p. 47 and for a recent essay on the topic that concludes that O'Connell was most likely a member see C. J. WOODS, 'Historical Revision: Was O'Connell a United Irishman?', Irish Historical Studies, Vol. 35, No. 138, Nov. 2006, pp. 173-183. Woods's argument is the most powerful and its conclusion less than ambiguous. Thanks to Patrick Geoghegan, TCD, for his help on this topic.

10 R. F. FOSTER, Modern Ireland, 1600-1972, London: Penguin Press, 1988, p. 279; BARDON, A History of Ulster, op. cit., p. 237.
} 
throat and dying a week later from his wounds. ${ }^{11}$ In 1803 , Robert Emmet staged a hopeless, ill-planned rising in Dublin, was later captured, tried and publicly executed. Both Tone and Emmet's speeches from the dock, after their convictions for treason, became standard reading for later generations of republicans and nationalists. However, there would be no further revolutions in Ireland for forty-five years.

\section{Catholic emancipation}

The foremost figure in Irish political life in the early decades of the nineteenth century was Daniel O'Connell. As noted above, O'Connell was no hasty revolutionary. He was barrister of note and campaigned through the $1810 \mathrm{~s}$ for Catholic emancipation. In early 1821 and again in 1825 the campaign seemed to be on the brink of success, when on two occasions bills to effect emancipation measures were passed in the House of Commons only to be defeated in the House of Lords. ${ }^{12}$ From 1825 Catholic Emancipation became the mobilisation point for Irish Catholics, the Catholic clergy and political liberals. In 1826 O'Connell campaigned successfully to get the small Catholic electorate, limited to forty-shilling freeholders, to support Protestant candidates who favoured emancipation. ${ }^{13}$ O'Connell built a popular mass movement and even though he was prohibited by law from taking a seat in parliament, he succeeded in winning a Co. Clare by-election against an Anglican in 1828. When emancipation was granted in 1829 it raised the property qualification for voting in county elections from 40 shillings to $£ 10$, thus the political base O'Connell had relied on was disenfranchised. ${ }^{14}$

On the night the bill passed, a friend joked to O'Connell that 'his career was now over' as his reason to agitate further was gone. ${ }^{15}$ " "Gone!" exclaimed O'Connell with a wide smile. "Isn't there a Repeal of the Union?", ${ }^{16}$ F.S.L. Lyons noted there was 'a small grain of truth submerged in a vast sea of misconception' to the 'tired old witticism that every time the English came within sight of solving the Irish question the Irish changed the question'. ${ }^{17}$ In reality the question changed rather little from the 1790s for nationalists of all creeds. It was to take control of Irish affairs in whatever manner that Britain would allow or be forced to allow on the road to ultimately achieving national independence.

\footnotetext{
${ }^{11}$ BARDON, A History of Ulster, op. cit., p. 237.

${ }^{12}$ GEOGHEGAN, King Dan, op. cit., pp. 188, 220-1.

${ }^{13} \mathrm{Ibid}$, p. 230-3. Note: Forty-shilling free holders were tenants who had lease for life on a house or land with an annual rent of at least 40 shillings. In 1793 this minimum qualification for enfranchisment was granted to Catholics as well as Protestants. It may have encouraged some landlords to further sub-divide land in order to gain political influence as more of their tenants would have voting rights. See D.J. HICKEY, \& J.E. DOHERTY, A Dictionary of Irish History, Dublin: Gill \& Macmillan, 1980, p. 177.

${ }^{14}$ An Act for the Relief of His Majesty's Roman Catholic Subjects, 10 Geo. 4 c. 7 (13 April 1829).

${ }^{15}$ GEOGHEGAN, King Dan, op. cit., p. 270.

${ }^{16}$ Ibid.

${ }^{17}$ F.S.L. LYONS, Ireland Since the Famine, London: Weidenfeld \& Nicolson, 1971, p. 15.
} 


\section{The Repeal Movement}

Following Catholic Emancipation there was much debate about the entry of Catholics into mainstream political life. O'Connell initially used the threat of reactivating the mass movement that had achieved Catholic Emancipation, but the Catholic hierarchy had ordered priests to desist from further political agitation. ${ }^{18}$ However, the 1830s did herald a sustained campaign against the payment of tithes. Tithes were a tax payable to the established Protestant, Church of Ireland, levied not just on co-religionists, but on all people holding property in a parish, whether they be Catholics or from other protestant faiths, such as Methodists, Quakers or Presbyterians. The early phase of the 'Tithe War' was marked by violence and a general withholding of tithes even by members of the Established Church. However when O'Connell and his followers at Westminster agreed upon an informal arrangement with the Whigs in 1835, violence subsided. O'Connell's move would draw later criticism as being collaboration. Between 1835 and 1841 O'Connell and the Irish party at Westminster acted as 'a corps in the whig-liberal-radical army rather than independently.${ }^{19}$ However by the early 1840s O'Connell felt that 'he and the other Irish members were wasting their time at Westminster. ${ }^{20}$ On the 15 th of April 1840, he established the Loyal National Repeal Association, known more commonly as the Repeal Association. In 1840, a twenty-six year old Protestant barrister of 'mixed English and Anglo-Irish' stock, Thomas Davis, joined O'Connell's Repeal Association. ${ }^{21}$ The mainstream Repeal Movement headed by O'Connell was supported by a middle class who elected 'gentry-merchant MPs' ${ }^{22}$ By the late 1830s these MPs were as much part of, as well as working within, the status quo. However the broader political expectations that were raised in the 1820 s, through mass mobilisation for emancipation, were not catered for in this arrangement. The vacuum was partly filled by a hugely popular movement which formed around Davis, known as Young Ireland. ${ }^{23}$

\section{Young Ireland and Repeal}

Like Tone and Emmet, Davis was educated at Trinity College, Dublin. Though Trinity was a Protestant university, Protestants, dissenters and, occasionally, Catholics attended. It was at the student debating society, the College Historical Society that, in 1840, Davis declared himself a nationalist with a desire to help his country. ${ }^{24}$ It was also at Trinity that he met John Blake Dillon, an anomalous Catholic in the student body. Charles Gavan Duffy, a Catholic, who had worked on newspapers in Belfast and Dublin, completed the triumvirate who launched The Nation, a newspaper that would promote cultural nationalism. In 1841, Davis wrote

${ }^{18}$ Alvin JACKSON, Ireland 1798-1998, Oxford: Blackwell, 1999, p. 37.

${ }^{19}$ Oliver MACDONAGH, 'Politics 1830-45', pp. 169-92 in VAUGHAN, A New History of Ireland, op. cit., p. 169.

${ }^{20}$ Robert SLOAN, William Smith O'Brien and the Young Ireland Rebellion of 1848, Dublin:

Four Courts Press, 2000, p. 9.

${ }^{21}$ FOSTER, Modern Ireland, op. cit., p. 311.

${ }^{22}$ Ibid., pp. 310-11.

${ }^{23}$ Ibid.

${ }^{24}$ LYONS, Ireland Since the Famine, op. cit., p. 104. 
an essay that asserted Ireland would not be ready for freedom until it had rediscovered its own history and culture. Davis believed that promoting a national identity distinct and separate from Britain was a necessary precursor to national independence. In his essay 'The History of Ireland' he noted: 'If Ireland were in national health, her history would be familiar by books; pictures, statuary and music [...]. These are the pillars of Independence. ${ }^{25}$ It is obvious that Davis felt that there was a dearth of knowledge about Irish history among Irish people and thus there was a lack of feeling or interest in Irish independence amongst the population. While Duffy became the paper's first editor, it was Davis who set its agenda. Indeed its first issue published on $15^{\text {th }}$ October 1842 gave its mission statement in verse:

'Tis a great day, and glorious. O Public! for you-

This October Fifteenth, Eighteen Forty Two!

For on this day of days, Lo THE NATION comes forth,

To commence its career of Wit, Wisdom, and Worth -

To give Genius its due - to do battle with Wrong -

And achieve things undreamed of as yet, save in song.

Then arise! fling aside your dark mantle of slumber,

And welcome in the chorus THE NATION's First Number. ${ }^{26}$

The relative ambiguity of this mission statement was characteristic of the early days of the Young Ireland movement. It advocated repeal and independence but was certainly not militant in the way Young Ireland would later become. Davis's own poetry put to musical airs, such as 'A Nation Once Again' and 'The West's Asleep' remain anthems of Irish nationalism. The last verse of 'Celts and Saxons', gives a fair reprise of his views, later embraced by the Fenians, on sectarianism:

We do not hate, we never cursed,

Nor spoke a foeman's word

Against a man in Ireland nursed,

Howe'er we thought he erred;

So start not, Irish-born man,

If you're to Ireland true,

We heed not race, nor creed, nor clan,

We've hearts and hands for you. ${ }^{27}$

Davis's vision for Ireland was of a country where the Irish-born, whether they be the descendents of Normans, Celts, Old English or Norsemen would find a harmony in nationhood by rediscovering their common heritage. To this end he wrote historical essays on Irish archaeology, poetry, art, music, ballads and poetry. The form of cultural nationalism which The Nation espoused proved to be ' $a$ runaway success'. ${ }^{28}$ It had a readership of as many as 250,000 by $1843 .{ }^{29}$

\footnotetext{
25 Thomas DAVIS, 'The History of Ireland', in idem, Thomas Davis, selections from his prose and poetry, London, Dublin, Belfast: The Gresham Publishing Company, 1910, p. 84.

${ }^{26}$ The Nation, 15 October 1845.

${ }^{27}$ Thomas DAVIS, 'Celts and Saxons', in idem, Thomas Davis, op. cit., p. 356.

${ }^{28}$ FOSTER, Modern Ireland, op. cit., p. 311.

${ }^{29}$ Ibid.
} 
From late 1842, having remained publicly neutral on the Repeal issue while serving as Lord Mayor of Dublin, O'Connell began mobilising for extraordinary extra-parliamentary agitation and declared 1843 was to be 'The Great Repeal Year ${ }^{30}$ To this end, in early 1843, O'Connell instructed his MPs, not to attend parliament, but to remain in Ireland to help prepare a series of monster meetings. The Nation used its considerable influence to promote O'Connell and Repeal. For Young Ireland federalism, as promoted by the Whigs, was not the solution. They believed, uncompromisingly, in simple repeal. The initial success of the movement that O'Connell led can be gathered from contemporary reports. Ciarán Ó Murchadha describes one such meeting in the introduction to his book The Great Famine, Ireland's, $1845-52$. On $15^{\text {th }}$ June 1843 a monster meeting took place at a racetrack outside Ennis, Co. Clare. In the weeks leading up to the meeting 120 mature trees where 'uprooted [...] and replanted in rows along the streets and the processional route outside the town boundaries'. ${ }^{31}$ These trees were decorated and augmented with 'triumphal arches' and banners. ${ }^{32}$ The meeting held on a mid-week holy day of obligation, Corpus Christi, ensuring that Catholics were free from their labours to attend. People came from up to 100 miles away which, considering that most would have had to walk indicates the excitement that the Repeal Movement had awoken in 1843. From 4 a.m. the town was thronged, while from 10.30 a.m. a slow moving procession led by bands and followed by the trade organisations and 6,000 horsemen. O'Connell addressed a mass audience that day, estimated by Repealers to be 'between 400,000 and 500,000', while opponents of the movement estimated an attendance of ' 150,000 to 200,000 ' ${ }^{33}$ This disparity is relatively unimportant for even the low figure indicates the ability of the movement to draw crowds that were too big for the forces of law and order to interfere with save by use of the military. It was O'Connell's intention to force the government into making concessions or enacting Repeal, those Irish people taking to the fields of Repeal oratory represented the vast majority of the population. There was also an implicit threat in organising such mass meetings. O'Connell always insisted the movement was to be non-violent but with the lyrical flourish of the Young Irelanders at The Nation coupled with O'Connell's political machine which relied once more on the local priests to mobilise their flocks, Ireland was a tinder box, and one spark might have ignited it.

\section{The road to revolution}

In September 1843, O’Connell resisted pressure from William Connor, a first cousin of the Chartist Feargus O'Connor, who wanted the Repeal Association to call a complete rent strike. O'Connell refused to countenance stepping outside the law. This seemed to contradict a statement he had made the previous month, that he would assemble a council of 300, a 'de facto Irish parliament' in Dublin by Christmas. ${ }^{34}$ Though he insisted 'We will be obedient to the Queen', he asserted,

${ }^{30}$ MACDONAGH, 'Politics 1830-45', op. cit., p. 183.

31 Ciarán Ó MURCHADHA, The Great Famine, Ireland's Agony, 1845-52, London: Bloomsbury, 2011, p. vi.

${ }^{32}$ Ibid.

${ }^{33}$ Ibid., p. xix.

${ }^{34}$ Paul BEW, Ireland: the Politics of Enmity, 1789-2006, Oxford: Oxford University Press, 2007, p. 162. 
'[...] we must have our own parliament'. ${ }^{35}$ The last and largest Repeal Meeting was set to take place on $8^{\text {th }}$ October at Clontarf, just north of Dublin, where in 1014 Ireland's High King, Brian Boru, had defeated the Norsemen. The Tory government, under Robert Peel, decided to call O'Connell's bluff and banned the meeting on its eve. They threatened to use gun boats to shell the crowd should it assemble. ${ }^{36}$ O'Connell cancelled the meeting and the crowds were persuaded to turn back before they reached Clontarf. The Freeman's Journal said that O'Connell cancelled the meeting in order to 'put the enemy in the wrong and, above all, respect for human life ${ }^{37}$ Young Ireland reacted through the pages of The Nation, pointing to the mass movement which had created 'a new class of men in 20 months'. 38 "Not since the French revolution, certainly none other, effected so miraculous and electric a change in the character of the people, ${ }^{39}$ Had the government let matters rest, this might have been the end of the Repeal Movement. However, they determined to prosecute O'Connell. Though campaigning for the repeal of a law was legal, O'Connell was arrested and charged on the basis of his August speech promising a council of 300 which was to be an Irish parliament. Between his arrest and trial O'Connell was feted in London and received a standing ovation from the opposition benches upon entering parliament. ${ }^{40} \mathrm{He}$ was convicted and sentenced to a fine and a year in prison. However, this was overruled by the House of Lords. Jailing O'Connell strengthened not only his own appeal but also the coffers of the Repeal Association which saw a four-fold rise in receipts for the 'Repeal Rent'. ${ }^{41}$ That O'Connell raised a mass movement and so quickly set it aside following first serious threat from the government indicated a flaw in his program. By remaining within the confines of the law he shackled the movement to predicable courses of action. Young Ireland in the pages of The Nation supported O'Connell in the aftermath of the Clontarf debacle, but the possibility of a popular and mobilised mass movement was lost to the Repealers.

On $20^{\text {th }}$ October, in the immediate aftermath of the government arresting O'Connell and others for sedition, a young MP who was a direct descendent of Brian Boru, William Smith O'Brien, decided to join the repeal movement sending ' $£ 5$, my first subscription to the Loyal Repeal Association of Ireland' ${ }^{42}$ O’Brien’s family had converted to Protestantism and had kept their status and estates. O'Brien had previously opposed the repealing the union but felt that Ireland could not expect justice, understanding or generosity from an English parliament and should rely on its 'own native energy and patriotism.' ${ }^{43}$ Thomas Davis, while active in organisations and with The Nation, did not play an active part in the public meetings for Repeal. When O'Connell was released from prison in September 1844, the Young Ireland camp feared he would once again engage in a parliamentary alliance

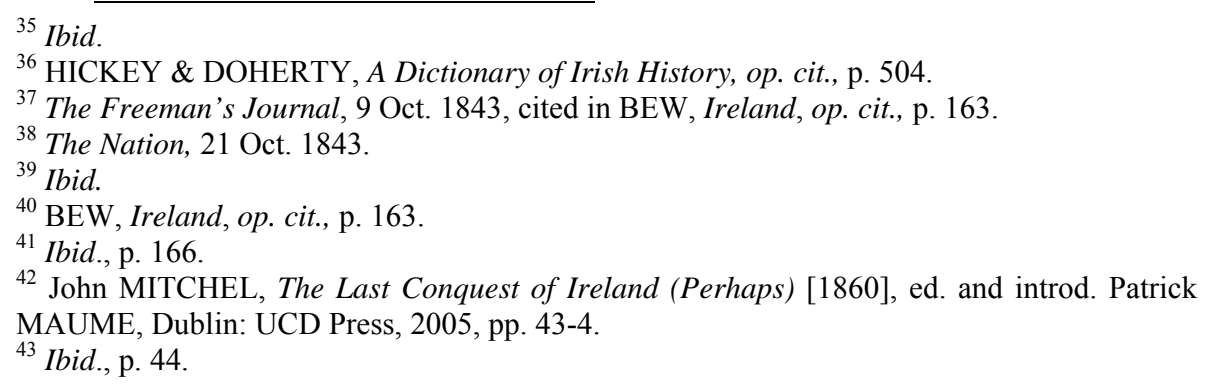


with the Whigs. Indeed, O'Connell did discuss a federal solution, whereas Young Ireland was unwillingly to accept anything short of repeal of the Act of Union, and would not be bought off by mere reform. ${ }^{44}$ Davis came to the fore in 1845 , in a conflict with O'Connell, over the latter's objection to the government's proposal to create non-denominational third level colleges in Ireland. ${ }^{45}$ Davis wanted young men of all creeds to be educated together in furtherance of his aim to achieve nationhood though a common discovery of a mutual past and hopeful future and based on toleration and nation. O'Connell's support for a Catholic university caused a major clash with Young Ireland. However, on $15^{\text {th }}$ September, after a short illness, Thomas Davis died. $^{46}$

\section{Famine and confederacy}

Prior to his death Davis had formed the ' 82 club, named after the year when Henry Grattan's parliament first sat in Dublin in 1782. One of the invited members of this green uniformed elite was another Trinity graduate and Presbyterian from Co. Derry, John Mitchel. Though a contributor to The Nation from 1843, Gavan Duffy gave Mitchel a salaried post as assistant editor in the weeks after Davis's death. Until 1847 when Mitchel split with The Nation, he wrote most of its political content. ${ }^{47}$ In 1846 the tensions between the O'Connellites and Young Ireland came to a head when O'Connell sought to form an alliance with the Whigs in order to oust Peel and the Tories. Such a compact was resisted by Young Ireland and at a series of meetings in June. O'Connell's son, John, asked the movement to shun newspapers that suggested a physical force route, proposed a resolution at the Repeal Association, that members 'repudiate the use of political force' ${ }^{48}$ This was strongly rejected by Thomas Francis Meagher. ${ }^{49}$ By the end of the year peace negotiations between Old Ireland and Young Ireland floundered leading to the formation in January 1847 of the Irish Confederation. ${ }^{50}$ The Confederation formed Confederate Clubs to rival the Repeal Clubs of the O'Connellites.

${ }^{44}$ James QUINN, John Mitchel, Dublin: UCD Press, 2008, p. 8.

${ }^{45}$ In 1845 the government's proposal to fund three non-denominational Queen's College in Ireland was strongly opposed by O'Connell with the support of the Catholic clergy. O'Connell was in favour of separate denominational colleges for Catholics and Protestants.

${ }^{46}$ Charles Gavan DUFFY, Short Life of Thomas Davis, London: T. Fisher Unwin; Dublin: Sealy, Bryers \& Walker, 1895, p. 241.

${ }^{47}$ QUINN, John Mitchel, op. cit., pp. 8-11.

${ }^{48} \mathrm{BEW}$, Ireland, op. cit., p. 184.

${ }^{49}$ Four speeches made by Meagher at the Conciliation Hall on 15 June, 22 June, 13 July and 26 July, 1846 are published in Thomas Francis MEAGHER, Meagher of the Sword, Speeches of Thomas Francis Meagher, 1846-1848, His narrative of events of July 1848, Personal Reminiscences of Waterford, Galway and his Schooldays, ed. Arthur Griffith, Dublin: M.H. Gill \& Son., 1916, pp. 5-37.

${ }^{50}$ The Irish Confederation may be viewed as the official organisation of the Young Ireland movement. It was founded 13 Jan. 1847. The Confederation demanded self-government and self-reliance for Ireland. The revolutionary ideas of James Fintan Lalor influenced John Mitchel and Michael Doheny but were too extreme for most of the Confederation's leaders. The French Revolution of 1848 further radicalised hard-liners including Thomas Francis Meagher and Mitchel who demanded the establishment of an Irish republic and published military tactics to be used in a rising. See HICKEY \& DOHERTY, A Dictionary of Irish History, op. cit., pp. 242-3. 
The winter of 1846 proved murderous for labourers and tenant farmers dependent on the potato for survival. After two successful harvests had been struck by blight, Ireland was in the midst of human calamity. Death and disease stalked the land. The government's reaction and efforts to alleviate helped ease the path of many from political discourse to thoughts of revolution. One person who saw the potential and highlighted the plight of the tenant farmers and labourers was James Fintan Lalor.

\section{James Fintan Lalor and the origins of Fenianism}

James Fintan Lalor, a hunchback, was described by Charles Gavan Duffy as being 'deaf, near sighted, ungainly and deformed'. 51 Duffy in his Four Years of Irish History 1845-1849 stated that that of all the men in the 1840s who 'preached revolutionary politics in Ireland' Lalor was the most 'original and intense, ${ }^{52}$ His writings advocated eschewing participation in parliamentary politics or reform and sought to mobilise people around a resource and cause which stood below their feet: the land itself. Denis Gwynn noted Lalor was an innovator who urged 'propaganda [...] in favour of agrarian revolution'. ${ }^{53}$ The use of propaganda was something at which the early Fenians and the Fenians involved in the Land War were adepts. Though Lalor's letters could be rambling, key phrases proved powerful as copy for banners years after his death in 1849. 'The land of Ireland for the people of Ireland to have and to hold from God above who gave it' was adapted into the more streamlined later Land League slogan 'The Land for the People'. 54 In a letter to John Mitchel, in June 1847, Lalor outlined his desire for a tabula rasa, which scorned a nationalist movement concerned with constitutional representation and the common law and introduced a highly emotive contra formula for Irish independence. In his effort to negate the 'conquest' Lalor's solution was to completely ignore it. ${ }^{55}$

In his first letter to The Nation in January 1847 Lalor declared his disdain for the Repeal movement: 'I will never give one shilling, or give my name, heart or hand, for such an object as the simple repeal by the British parliament of the Act of Union' ${ }^{56}$ Lalor would have nothing to do with an organisation that limited itself to mere Repeal. He saw the potential of the Repeal movement to be a much more potent vehicle, which could strive for complete independence from Great Britain. The engine which should drive this movement he felt was the land question: ' $A$

${ }^{51}$ Denis GWYNN, Young Ireland and 1848, Cork: Cork University Press, 1949, p. 111; Charles Gavan DUFFY, Four Years of Irish History: 1845-1849: A sequel to Young Ireland, London, Paris, New York: Cassell, Peter, Galpin \& Co, 1883, p. 464.

${ }^{52}$ DUFFY, Charles Gavan Duffy, op. cit., p. 464. This is also quoted in GWYNN, Young Ireland, op. cit., pp. 132-133.

${ }^{53}$ GWYNN, Young Ireland, op. cit., p. 129.

${ }^{54}$ Frank RYNNE, “"This extra parliamentary propaganda": Land League posters', History Ireland, Vol. 16, No. 6, Nov./Dec. 2008, pp. 38-41. Note: available online $<\mathrm{http}: / /$ www.historyireland.com//volumes/volume16/issue6/features/?id=114213> [retrieved 1 Sept. 2011].

55 James Fintan LALOR to John Mitchel, 21 June 1847, in L. FORGARTY (ed.), James Fintan Lalor: Patriot and Political Essayist, 1907-1849, Dublin: The Talbot Press, 1918, p. 44.

${ }^{56}$ James Fintan LALOR to Charles Gavin Duffy, 11 Jan. 1847, in ibid., p. 2. 
mightier question is in the land - one beside which Repeal dwarfs down into a petty parish question. ${ }^{57}$ Lalor felt if his suggestion as to the battle ground was chosen, Irish separatists would not be merely 'asserting old principles' nor be a 'humble and feeble imitator and follower of other countries - but an original inventor, propounder, and propagandist, in the van of the earth, and leading the nations'. ${ }^{58}$ Furthermore, he asserted that by organising and agitating on the issue of land tenure, Ulster would not 'be on her flank' but 'at her side'. ${ }^{59}$ In this Lalor may have been prophetic, as the Land League initially had appeal in Ulster, where the rhetoric of Irish nationalism was conveniently discarded, so as not to alienate the Ulster unionist tenants who were mobilising around the land question.

Lalor felt that the disintegration of society caused by famine, 'the visitation of God in the order of nature', had returned to the people an original right: 'the right of establishing and entering into a new social relationship' beyond the strict confines of written law. ${ }^{60}$ In this way Lalor's argument allowed later generations to conceptualise a path to independence without reference to parliamentary or constitutional rights but rather based on the de facto rights of occupancy and the whim of the majority to reject the old order and then protect their declared interests. In May, Daniel O'Connell died on his way to Rome, leaving his ineffectual son, John, at the helm of the Repeal Movement.

By June, Lalor's rhetoric had hardened and his message was less equivocal. In a letter to Mitchel outlining the reasons he would not be allowing his name to go forward for membership of 'The Irish Council' and indeed whether he should even still consider himself a member of the Confederation, Lalor asserted that his object 'to repeal the Conquest - not any part or portion but the whole and entire conquest of seven hundred years - a thing much more easily done than to repeal the Union. ${ }^{61}$

\section{United Irishman and revolution}

Mitchel took up Lalor's creed causing a split with Gavan Duffy and many of the leading Confederates. Lalor advocated a trained disciplined force to resist such

\footnotetext{
${ }^{57}$ Ibid., pp 2-3.

${ }^{58}$ Ibid., p. 3.

${ }^{59}$ Ibid. Note: Lalor uses the difference between the military term 'on her flank' and 'on her side' to indicate that he felt that despite having a more equitable form of tenancy known as the Ulster Custom, Protestant tenants in Ulster would still be persuaded to take actual ownership of the land. The Ulster Custom allowed for tenants to sell their interest in the land they rented when leaving a farm. It was mostly widely practiced in Ulster and was only made law for the whole island in 1881 during the Land War of 1879-82.

${ }^{60}$ Lalor, 'A New Nation, [...]' 19 Apr. 1847, in FORGARTY, Lalor, op. cit., pp. 13-14.

${ }^{61}$ James Fintan LALOR to John Mitchel, 21 June 1847, in ibid., pp. 43-4. Note: The Irish Council was called together by William Smith O'Brien in 1847 and drew its members from both the professional and landlord classes as well as representatives of both the Repeal movement and the Confederation. It met in private in May and June 1847 for the purpose of practical remedies for the dealing with the Famine. However as matters deteriorated in Ireland the former two groupings supported coercion and the project collapsed. See SLOAN, William Smith O'Brien, op. cit., pp 186-7; HICKEY \& DOHERTY, A Dictionary of Irish History, op. cit., p. 244.
} 
intervention and stated: 'I want a prepared, organised, and resistless revolution', ${ }^{62}$ Resolutions proposed by William Smith O'Brien for the confederacy to eschew the type of violent rhetoric Mitchel was propagating were adopted in February 1848. Mitchel set up a new newspaper named after the revolutionaries of '98, United Irishman. Mitchel in the first issue of the United Irishman published on 12th February 1848 quoted Tone: 'Our Independence must be had at all hazards. ${ }^{63}$ In an editorial addressed to the Earl of Claredon, 'calling himself the Lord Lieutenant and Governor General of Ireland', Mitchell called for a 'Holy war to sweep this Island clear of the English name and nation. ${ }^{, 4} \mathrm{He}$ stated that 'We differ from the illustrious conspirators of 98 [...] not one iota' ${ }^{65}$ Mitchel called for an open rebellion, for those did not have a gun to sell their 'garment to buy one ${ }^{66}$ He invoked the phrase associated with the French Revolution asking the people to 'Let your ears drink in the blessed words Liberty, Fraternity, Equality' ${ }^{67}$ Following the French Revolution of 1848, the words Liberty, Fraternity, Equality were enshrined in the constitution of the Second Republic. ${ }^{6}$ The French Revolution of February was imitated in many continental European countries. The language used by Mitchel, indicates that he was determined to use United Irishman to force the government to take action against the paper and himself thus provoking a revolution in Ireland.

After a mass demonstration in Dublin on 21 March 1848, at which O'Brien demanded arms and the formation of a national guard, he, Thomas Francis Meagher and Mitchel were indicted for sedition. At the end of March, only one month after the provisional republican government took power in Paris, a Young Ireland delegation including Meagher and O'Brien arrived in Paris and met with the foreign minister of the provisional government, Alphonse Lamartine. ${ }^{69}$ Though, at first Lamartine said that the delegation had sought armed assistance for Ireland, O' Brien denied this. ${ }^{70}$ Ultimately, Lamartine did not offer aid to the Irish as he was under severe pressure from the British government not to. ${ }^{71}$ The eventual trail for sedition failed to convict O'Brien and Meagher while Mitchel, in an effort to buy time, pleaded abatement to the sedition charge. In April 1848 the government was under pressure both in Britain from the Chartist movement demands and in Ireland with

${ }^{62}$ Ibid., p. 45.

${ }^{63}$ United Irishman, 12 Feb. 1848.

${ }^{64}$ Ibid.

${ }^{65}$ Ibid.

${ }^{66}$ Ibid.

${ }^{67}$ Ibid.; 'Ireland. The third French Revolution has awakened more noisy sympathies', The Spectator, 11 April 1848 <http://archive.spectator.co.uk/article/11th-march-1848/5/ireland_he-third-french-revolution-has-awakened-m>.

${ }^{68}$ Constitution de 1848, 4 novembre 1848: <http://www.conseil-constitutionnel.fr/conseilconstitutionnel/francais/la-constitution/les-constitutions-de-la-france/constitution-de-1848-iierepublique.5106.html>.

${ }^{69}$ KINEALY, Repeal and Revolution, op. cit., p. 142; SLOAN, William Smith O'Brien, op. cit., pp. 219-21.

${ }^{70}$ Robert Sloan notes that Lamartine contradicted himself as to whether the Irish had requested arms, while O'Brien, the only member of the Young Ireland delegation to meet Lamartine alone, disputed the claim. See SLOAN, William Smith O'Brien, op. cit., pp. 21920; KINEALY, Repeal and Revolution, op. cit., p. 142.

71 Joseph DENIEFFE, A Personal Narrative of the Irish Revolutionary Brotherhood, Shannon: Irish University Press, 1969, p. v. 
the increasing militancy preached by Mitchel. Smith O'Brien had hoped for a revolution that would be both constitutional and peaceful. The same month Irish Americans mobilised and large donations were made for the cause of rebellion at home, especially in New York where there was drilling of regiments that would be dispatched to Ireland in the event of a rising. The ability of Irish Americans to organise for militant action in Ireland and to raise money for the cause of Irish revolution was thereafter an abiding resource which Irish revolutionaries would draw on. The first Irish-American militant revolutionary movement had formed in 1848 , in advance of a proposed rising in Ireland set its priority as the weekly drilling of members and their training in military skills. This organisation was called the Irish Republican Union. ${ }^{72}$

Between 25th and 27th May 1848, John Mitchel was tried and sentenced to 14 years of transportation under the new Treason Felony Act, and United Irishman was repressed. The Treason Felony Act (1848) allowed for certain treason offences to be tried as felonies, and therefore they would not carry a mandatory death penalty. ${ }^{73}$ These events hardened Lalor's resolve for a no compromise assertion of an Irish right to independence based on peasant proprietorship. In June 1848, in his first letter to a new publication he helped found, Irish Felon, Lalor asserted 'Not to Repeal the Union, then, but to repeal the Conquest'; he wanted to 'found a new nation and raise up a free people, and strong as well as free, and secure as well as strong, based on a peasantry rooted like rocks in the soil of the land. ${ }^{, 74}$ In the same letter, Lalor put it bluntly: 'The soil of Ireland for the people of Ireland, to have and to hold from God alone who gave it. ${ }^{, 75}$

\section{The 1848 Rebellion}

By June, Gavan Duffy and other leading confederates had become fully committed to revolt. Duffy wrote to Smith O'Brien urging him to lead the endeavour. Yet, Smith O'Brien was still hopeful that the mere threat of a rising would somehow bring the government to heal. As the summer progressed he toured Confederate Clubs to great welcomes and marching displays. ${ }^{76}$ Robert Sloan asserts that the Rebellion of 1848 was induced rather than caused. By introducing a bill to suspend habeas corpus in Ireland, the government forced the reluctant rebel leader's hand. John Francis Meagher, as well as co-founder of The Nation John Dillon, led the pressure on O'Brien for revolt. When it was put to him by Dillon that the three courses of action open to them were, accept imprisonment, go into exile or

72 Ibid.

${ }^{73}$ Brigitte ANTON, 'Mitchel, John (1815-1875)', Oxford Dictionary of National Biography, Oxford University Press, Sept. 2004; online edition, Jan. $2008<$ http://www.oxforddnb.com/vi ew/article/18828> [accessed 31 July 2009]; R. V. COMERFORD, 'Lalor, James Fintan (1807-1849)', Oxford Dictionary of National Biography, Oxford University Press, 2004 $<$ http://www.oxforddnb.com/view/article/15906> [accessed 31 July 2009].

74 James Fintan LALOR, Irish Felon, 24 June 1848, quoted in FORGARTY, Lalor, op. cit., p. 59.

75 Ibid., p. 57.

${ }^{76}$ R.V. COMERFORD, Charles J. Kickham: A Study in Irish Nationalism and Literature, Portmarnock: Wolfhound Press, 1979, p. 22; SLOAN, William Smith O'Brien, op. cit., pp. 238-46. 
insurrection, O'Brien soon accepted the latter course. The rebellion of 1848 was doomed from the start. It consisted of O'Brien and other leaders travelling around Co. Wexford, Kilkenny and Tipperary in an effort to raise the people. In some cases, priests interfered with these plans 'using all their influence to oppose rebellion' while in others the local people, seeing the miserable unpreparedness and lack of provisions, refused to join them. ${ }^{77}$ Among the local leaders they encountered, John O'Mahony, founder of the Fenian Brotherhood, impressed them with his 'soldierly appearance', while Charles Kickham was having pikes made when O'Brien and Meagher arrived in Mullinahone, Co Tipperary, on $25^{\text {th }}$ July. $^{78}$ On 29 July, near Ballingarry, Co. Tipperary, O'Brien and a few hundred 'colliers' with about 70 of them armed after a fashion encountered 45 Royal Irish Constabulary, under command of Sub-Inspector Thomas Trant. ${ }^{79}$ Trant led his men to a house owned by a widow named McCormack. Acting as O'Brien's aide de camp at Ballingarry was James Stephens, later founder of the Irish branch of the Fenian movement, the Irish Revolutionary or Republican Brotherhood. ${ }^{80}$ The rising culminated in a charge on the police who killed one man with their volley. At this the people dispersed.

\section{Aftermath}

After the failed rising, leading Young Irelanders such as Smith O'Brien and Thomas Francis Meagher were convicted and transported to Van Diemen's Land (Tasmania), while others such as John Blake Dillon fled the country. Stephens and others secured the assistance of Skibbereen solicitor McCarthy Downing in effecting their escape to France ${ }^{81}$ However, in exile in Paris, John O'Mahony and James Stephens honed their skills and learned lessons from the failures of the 1840s. In 1853 O'Mahony went to New York where with other exiles such as Joseph Denieffe and Michael Doheny, they engaged in organising Irish American separatist organisations. In 1856 Stephens returned to Ireland with the view to re-organising the remnants of the ' 48 movement for revolution. On St Patrick's Day 1858, Stephens, Thomas Clarke Luby and Joseph Denieffe founded the Irish Revolutionary, later Irish Republican Brotherhood. Unlike the movements of the 1840 s, the IRB was to be secret and strictly revolutionary. In Skibbereen Stephens was introduced by McCarthy Downing to Jeremiah O'Donovan Rossa, who had organised The Phoenix Literary Society in the town. In 1861 the IRB emerged from the shadows when they stage-managed the funeral of Young Ireland exile Terence Bellew MacManus, whose body had been returned from the USA with the help of the Fenian Brotherhood. In 1863, Stephens opened the Irish People newspaper. ${ }^{82}$ In the United States, the Fenian Brotherhood could organise and raise funds without fear of prosecution. In the aftermath of the Famine and the Young Ireland rebellion the vast numbers of Irish emigrants, who brought with them a sense of injustice at

\footnotetext{
${ }^{77}$ SLOAN, William Smith O'Brien, op. cit., pp. 238-75.

${ }^{78}$ Ibid., p. 254; COMERFORD, Charles J. Kickham, op. cit., p. 23.

${ }^{79}$ SLOAN, William Smith O'Brien, op. cit., p. 276.

${ }^{80}$ Marta RAMON, A Provisional Dictator, James Stephens and the Fenian Movement, Dublin: UCD Press, 2007, pp. 34-5.

${ }^{81}$ Fitzmaurice RM to Lord Naas, 27 Dec. 1858, National Archives of Ireland, Irish Crime Records, 16, Fenian Police Reports, box 1.

${ }^{82}$ RYNNE, 'This extra parliamentary propaganda', op.cit.
} 
the hands of both government and landlord, provided the new revolutionary movement with recruits and funding. Though the Fenian Rising of 1867 was another dismal failure, the movement was reborn in the late 1870s when a Protestant landlord, Charles Stewart Parnell, forged a compact with John Devoy, leader of the Fenian Clan-na-Gael, and Michael Davitt, a recently released IRB man who sought to foment revolution by mobilising the tenant farmers. In 1881 John Devoy, speaking of the Fenian movement, remarked: 'The early members were mainly brought into the movement by men who had kept alive a remnant of the organisation started by James Fintan Lalor in 1849, and the destruction of the foreign landlord system was one of the cherished objects of the majority. ${ }^{83}$ The Land War confirmed the continuation of this revolutionary enterprise.

\section{Conclusion}

According to T.W. Moody, the founders of Fenianism believed that 'to pursue particular national objectives before self-government had been won would be a dangerous deviation ${ }^{84}$ However, the founders of Fenianism did use Lalor's themes in their propaganda. Marta Ramón has noted that, in 1855, eight years prior to the establishment of the Irish People, Thomas Clarke Luby had launched a short-lived newspaper called Tribune. In its third issue an editorial commenced:

All the land of Ireland belongs to the People of Ireland, in aggregate, to be distributed and made use of just so as best may serve happiness, prosperity, peace and security of the People of Ireland. [...] But the Land itself is the Nation's alone, and the Nation may, when it likes, resume every acre of it for the purpose of re-distribution. ${ }^{85}$

This statement is the missing rhetorical link between Lalor and Fenianism and clearly indicates that Luby's Tribune evangelised Lalor's creed. The compact between Parnell and the Fenian movement on both sides of the Atlantic led to the Land War 1879-82. This was organised at a grassroots level by deeply embedded IRB and Fenians, some of who had returned from America years in advance on the Land League agitation. ${ }^{86}$ In 1879 the Irish National Land League was founded and, like the earlier Repeal and Confederate organisations, the land war combined mass meetings with a revolutionary mobilising in the remotest parts of Ireland. Devoy in his Recollections of an Irish Rebel stated that, as the revolutionary group that Lalor founded remained intact after his death and was merged with the Irish Republican Brotherhood by James Stephens in 1858, 'James Fintan Lalor might be said to be

\footnotetext{
${ }^{83}$ John DEVOY, The Land of Eire: The Land League it Origin, Progress and Consequences preceded by a concise History of the Various Movements which have Culminated in the Last Great Agitation, with a descriptive and Historical Account of Ireland From The Earliest Times to the Present Day, New York: Patterson \& Neilson, 1883, p. 3.

${ }^{84}$ T.W. MOODY, Davitt and the Irish Revolution, 1946-82, Oxford: Clarendon Press, 1982, p. 40.

${ }^{85}$ Tribune (Dublin), 17 Nov. 1855, quoted in RAMÓN, 'Introduction', Lalor, 'The Faith of the Felon' and other writings, p. 47.

${ }^{86}$ RYNNE, Permanent Revolutionaries: op. cit., pp. 245-9.
} 
the real Father of Fenianism, as well as the Land League, ${ }^{87}$ Lalor's influence stretched from his comrades who were the founders of, or early members of, the Fenian movement down to Pearse and the revolutionaries of 1916. The failure of O'Connell in 1843 heralded the beginning of the articulation of an unconstitutional approach to the separation of Ireland from the United Kingdom. While it can only be speculated what may have been the outcome had O'Connell taken his moral arguments to the physical force level in 1843, it is clear that during the Land War of 1879-82 and more successfully during the revolutionary period, a combination of a political front supported by physical force proved to be effective for nationalists who were determined to break with the UK.

The new approach was best articulated in literary form by John Mitchel in the 1860s. Having escaped Van Diemen's Land in 1853 he settled in the USA and wrote scathingly of England articulating a sense of injustice in his book The Last Conquest of Ireland (Perhaps), first published in 1860, in which he liberally quoted from Her Majesty's government statistics and added his own vitriolic interpretation of them to further the thesis that the Irish Famine was a deliberate genocide. He concluded: 'The Almighty, indeed, sent the potato blight. But the English created the Famine'. ${ }^{8}$ Mitchel's assertion that the Famine was a genocide caused by the 'English government' allowed the Irish republican rhetoric to assimilate and propagate the Famine as a recent incident in the cannon of British injustice that demanded remedy. He predicted that: 'The passionate aspiration of Irish nationhood will out-live the British Empire. ${ }^{89}$ Though both the Young Ireland and Fenian rebellions were failures, it was from Mitchel, Lalor, and Davis's ideas that Pearse and his generation of Fenians gained the most inspiration. It was the young followers of Lalor and Young Ireland who created the Fenian movement and the Fenian orthodoxy. It was their ideas that paved the way for advanced Nationalists to emerge in the late 1870s and early 1880 s, espousing a populist cause, which led to the creation of The Irish National Land League. The Land League established an administrative and organisational machine along governmental lines forty years before the First Dáil of $1919-21 .^{90}$ It was from Davis that the resurgence of Irish culture and language in the 1880s and 1890s emerged. Following the execution of Pearse and other leaders of the 1916 Rising, the population previously apathetic to revolt embraced militant nationalism and by 1920 much of southern Ireland was outside the rule of law, while six of Ulster's nine counties were separated from the rest of the island by the Government of Ireland Act $1920 .^{91}$ The Young Ireland Rising of 1848 put notions of armed rebellion to the fore in the minds of many young men who participated or wished they had. Secret rather than open societies, revolution rather than

${ }^{87}$ John DEVOY, Recollections of an Irish Rebel. The Fenian Movement, its Origins and Progress, Methods of Work in Ireland and in the British Army. Why it failed to achieve its Main Object and Exercised Great Influence on Ireland's Future, New York, Shannon: Irish University Press, 1969, p. 17. Note: Devoy incorrectly gives Lalor's year of death as 1853; in fact he died on 27 December 1849.

${ }^{88}$ MITCHEL, The Last Conquest of Ireland (Perhaps), op. cit., p. 219.

${ }^{89} \mathrm{Ibid}, \mathrm{p} .220$.

${ }^{90}$ The First Dáil (1919-21) was established in January 1919 by candidates elected as MPs in the December 1918 general election who refused to recognise the UK parliament as the legitimate government of Ireland and declared Ireland an independent republic.

${ }^{91}$ Those six counties became Northern Ireland and remained within the United Kingdom. 
constitutionalism continued right through to the $21^{\text {st }}$ century despite the change in the political landscape. The two main political parties in the 26 counties since the 1930s have been Fianna Fáil and Fine Gael, who both claim origins in the 1916 Rising and trace their political polarisation to the sides their founders took in the Civil War (1922-3), which pitted anti-Treaty republicans against Free State troops militarily supported by the UK. Elements of the former formed Fianna Fáil and the latter, Fine Gael. However the partition of Ireland in 1920 allowed for the continuation of an armed force tradition in Irish nationalism down to the present day. By the late 1960s and in the later 'Troubles' in Northern Ireland the rhetoric established by Young Ireland and the Fenians was on one hand kept alive as the national origin myth by the two main democratic parties in the Republic of Ireland and conversely was also drawn on by Sinn Féin and its now disbanded armed wing, the Provisional IRA, as well as other militant nationalist and republican organisations, as justification for their armed struggle in furtherance of a united Ireland. Since the 1998 Good Friday agreement, which saw the Provisional IRA disarm and Sinn Fein enter power-sharing in Northern Ireland, so-called dissident republicans have claimed the tradition as their own and effect to continue an armed struggle against British rule in Northern Ireland. ${ }^{92}$ The revolutionary tradition in Irish politics was recently labelled by Irish Times writer Colm Keena, in an article questioning Sinn Fein's suitability for government in Ireland, as a 'virus of militant nationalism' that 'needed to be isolated and killed before it infected coming generations'. ${ }^{93}$ What is clear is that the political ideals of militant republicanism and nationalism which emerged in the late 1840s have remained a source of origin myth and legitimacy for constitutional political parties that emerged from it over the last century while, conversely, they are still drawn on to legitimise armed nationalist opposition to a British role in Northern Ireland down to this day.

\section{Bibliography}

BEW, Paul. Ireland: the Politics of Enmity, 1789-2006. Oxford: Oxford University Press, 2007, 613 p.

BYRNE, Miles. Notes of an Irish Exile of 1798 being the chapters from Miles Byrne's Book relating to Ireland. Dublin: Maunsel \& Company, 1907, 301 p.

COMERFORD, R.V. Charles J. Kickham: A Study in Irish Nationalism and Literature. Portmarnock: Wolfhound Press, 1979, 255 p.

DAVIS, Thomas. Thomas Davis, selections from his prose and poetry. London, Dublin, Belfast: The Gresham Publishing Company, 1910, 367 p.

\footnotetext{
92 'Dissident republican suspects: Bail refused in Belfast case', BBC, New Northern Ireland, $<\mathrm{http}: / /$ www.bbc.com/news/uk-northern-ireland-28374375> [accessed 28 July 2014]; see also a photo gallery: Michael DEBETS, 'Dissident Republicans commemorate the 1916 Easter Rising in Dublin', 21 April $2014<\mathrm{http} / /$ www.demotix.com/news/4530144/dissidentrepublicans-commemorate-1916-easter-rising-dublin\#media-4529844> [accessed 28 July 2014].

${ }_{93}$ Colm KEENA, 'Questions about Gerry Adams's motivation remain', The Irish Times, 11 June 2014.
} 
DENIEFFE, Joseph. A Personal Narrative of the Irish Revolutionary Brotherhood. Shannon: Irish University Press, 1969, 293 p. (Note: This is a facsimile of the 1906 New York first edition with an added introduction by Seán Ó Lúing.)

DEVOY, John. Recollections of an Irish Rebel. The Fenian Movement, its Origins and Progress, Methods of Work in Ireland and in the British Army. Why it failed to achieve its Main Object and Exercised Great Influence on Ireland's Future. New York, Shannon: Irish University Press, 1969, 489 p. (Note: This edition is a facsimile of the 1929 New York edition with an added introduction by Seán Ó Lúing.)

The Land of Eire: The Land League it Origin, Progress and Consequences preceded by a concise History of the Various Movements which have Culminated in the Last Great Agitation, with a descriptive and Historical Account of Ireland From The Earliest Times to the Present Day. New York: Patterson \& Neilson, 1883, $220 \mathrm{p}$.

DONNELLY, James S., Jr. 'The Great Irish Potato Famine', pp. 356-71 in W. E. VAUGHAN (ed.), A New History of Ireland V, Ireland Under The Union 18011870, Oxford: Oxford University Press, 1989, 839 p.

DUFFY, Charles Gavan. Short Life Thomas Davis. London: T. Fisher Unwin; Dublin: Sealy, Bryers \& Walker, 1895, 250 p.

Four Years of Irish History, A Sequel to Young Ireland. London, Paris, New York: Cassell, Peter, Galpin \& Co, 1883, 780 p.

FOSTER, R. F. Modern Ireland, 1600-1972. London: Penguin Press, 1988, 688 p.

FORGARTY, L. (ed.). James Fintan Lalor: Patriot and Political Essayist, 19071849. Dublin: The Talbot Press, 1918, 154 p.

GEOGHEGAN, Patrick M. King Dan, The Rise of Daniel O'Connell, 1775-1829. Dublin: Gill and Macmillan, 2008, 337 p.

Robert Emmet, A Life. Dublin: Gill \& MacMillan, 2002, 348 p.

GWYNN, Denis. Young Ireland and 1848. Cork: Cork University Press, 1949, $325 \mathrm{p}$.

HICKEY, D. J. \& DOHERTY, J.E. A Dictionary of Irish History. Dublin: Gill \& Macmillan, 1980, 615 p.

JACKSON, Alvin. Ireland 1798-1998. Oxford: Blackwell, 1999, 507 p.

KINEALY, Christine. Repeal and Revolution 1848 and Ireland. Manchester: Manchester University Press, 2009, 318 p.

KEENA, Colm. 'Questions about Gerry Adams's motivation remain', The Irish Times, 11 June 2014.

MEAGHER, Thomas Francis. Meagher of the Sword, Speeches of Thomas Francis Meagher, 1846-1848, His narrative of events of July 1848, Personal Reminiscences of Waterford, Galway and his Schooldays, ed. Arthur GRIFFITH. Dublin: M.H. Gill \& Son., 1916. 352 p. 
MITCHEL, John. The Last Conquest of Ireland (Perhaps) [1860], ed. and introd. Patrick MAUME. Dublin: UCD Press, 2005, p. 240.

Ó MURCHADHA, Ciarán. The Great Famine, Ireland's Agony, 1845-52. London: Bloomsbury, 2011, 252 p.

MOODY, T.W. Davitt and the Irish Revolution, 1846-82. Oxford: Clarendon Press, 1982, $674 \mathrm{p}$.

O’NEILL DAUNT, William J. Personal Recollections of the Late Daniel O'Connell, M.P. 2 Vols. London: Chapman and Hall, 1848, 643 p.

QUINN, James. John Mitchel. Dublin: UCD Press, 2008, 108 p.

PEARSE, P. H. The Sovereign People. Dublin: Whelan \& Son, 1916, 20 p.

RAMON, Marta. A Provisional Dictator, James Stephens and the Fenian Movement. Dublin: UCD Press, 2007, 317 p.

RYNNE, Frank. 'Focus on the Fenians, the Irish People trials, November 1865 January 1866'. History Ireland, Vol. 13, No. 6, Nov./Dec. 2005, pp. 41-6. Available online $<$ http://www.historyireland.com/18th-19th-century-history/focus-on-thefenians-the-irish-people-trials-november-1865-january-1866/> [accessed 10 June 2014].

- Permanent Revolutionaries: The IRB and the Land War in Skull, Co. Cork, 1879-82. PhD Thesis, Trinity College Dublin, Jan. 2014, 278 p.

“"This extra parliamentary propaganda": Land League posters'. History Ireland, Vol. 16, No. 6, Nov./Dec. 2008, pp. 38-41. Available online $<$ http://www.historyireland.com//volumes/volume16/issue6/features/?id=114213> [accessed 1 Sept. 2011].

SLOAN, Robert. William Smith O'Brien and the Young Ireland Rebellion of 1848. Dublin: Four Courts Press, 2000, 320 p.

TONE, Theobald Wolfe. An Argument on Behalf of the Catholics of Ireland. Belfast: The Society of the United Irishmen, 1791, 31 p.

WOODS, C. J. 'Historical Revision: Was O'Connell a United Irishman?', Irish Historical Studies, Vol. 35, No. 138, Nov. 2006, pp. 173-183.

\section{Newspapers}

The Freeman's Journal.

The Nation.

The Irish Times.

The Spectator.

The United Irishman. 


\section{Online sources}

Constitution de 1848, 4 novembre $1848:<$ http://www.conseilconstitutionnel.fr/conseil-constitutionnel/francais/la-constitution/les-constitutionsde-la-france/constitution-de-1848-iie-republique.5106.html $>$ [accessed 10 July 2014].

KELLY, James. 'Politics and Administration in Ireland, 1770-1815'. UCC Multitext Project in Irish History: <http://multitext.ucc.ie/d/Politics_and_Administration_in_I reland_1770-1815> [accessed 10 June 2014].

'Ireland. The third French Revolution has awakened more noisy sympathies', The Spectator, 11 March 1848: <http://archive.spectator.co.uk/article/11th-march1848/5/ireland_he-third-french-revolution-has-awakened-m $>$ [accessed 10 July 2014].

Oxford Dictionary of National Biography. Oxford University Press, 2004:

$<\mathrm{http}$ ://www.oxforddnb.com>.

'Dissident republican suspects: Bail refused in Belfast case', $B B C$, New Northern Ireland: <http://www.bbc.com/news/uk-northern-ireland-28374375> [accessed 28 July 2014].

DEBETS, Michael. 'Dissident Republicans commemorate the 1916 Easter Rising in Dublin', 21 April 2014: <http://www.demotix.com/news/4530144/dissidentrepublicans-commemorate-1916-easter-rising-dublin\#media-4529844> [accessed 28 July 2014]. 